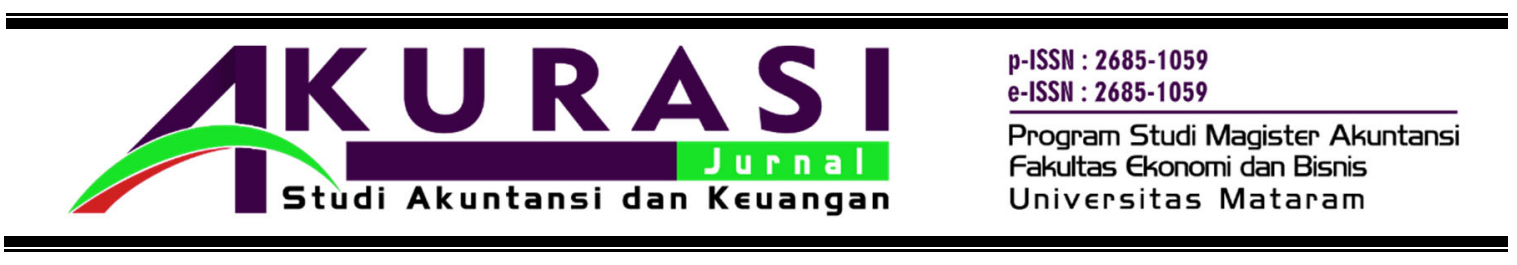

\title{
PENGARUH PENGUNGKAPAN CORPORATE SOCIAL RESPONSIBILITY DAN GOOD CORPORATE GOVERNANCE TERHADAP NILAI PERUSAHAAN SEKTOR PERBANKAN
}

\author{
Susilawati ${ }^{1}$ \\ ${ }^{1}$ Fakultas Ekonomi dan Bisnis Universitas Mataram, email : susiw976@gmail.com
}

\begin{tabular}{ll}
\hline INFORMASI ARTIKEL & ABSTRAK \\
\hline Article history: & Penelitian ini bertujuan untuk menguji pengaruh pengungkapan \\
Dikirim tanggal: 11/05/2019 & Corporate Social Responsibility (CSR) dan Good Corporate Governance \\
Revisi pertama tanggal: date & (GCG) terhadap nilai perusahaan. Ukuran perusahaan, leverage dan \\
Diterima tanggal: date & profitabilitas digunakan sebagai variabel kontrol. Pengujian dilakukan \\
Tersedia online tanggal 29/06/2019 & pada 32 perusahaan sektor perbankan yang tercatat di Bursa Efek \\
& Indonesia selama periode 2015-2017 dengan menggunakan teknik \\
& pengambilan sampel purposive sampling. Analisis data menggunakan \\
& regresi linier berganda. Hasil penelitian menunjukkan bahwa GCG \\
& berpengaruh positif dan signifikan terhadap nilai perusahaan, tetapi \\
& pengungkapan CSR tidak berpengaruh terhadap nilai perusahaan. \\
& Leverage dan profiabilitas sebagai variabel kontrol berpengaruh \\
& signifikan terhadap nilai perusahaan, sedangkan ukuran perusahaan tidak \\
& mempengaruhi nilai perusahaan. Hasil penelitian ini memberikan \\
& implikasi bahwa tata kelola perusahaan yang baik berperan dalam \\
menciptakan peningkatan nilai perusahaan. Di sisi lain kepedulian dan \\
keterlibatan perusahaan dalam investasi sosial seperti CSR akan \\
memberikan legitimasi perusahaan dalam beroperasi sehingga dapat \\
memperoleh dukungan stakeholder untuk menjamin kelangsungan hidup \\
perusahaan dalam jangka panjang.
\end{tabular}

Kata kunci: Nilai Perusahaan, Corporate Social Responsibility (CSR), Good Corporate Governance (GCG), Ukuran Perusahaan, Leverage, Profitabilitas.

\begin{abstract}
This study aims to examine the effect of disclosure of Corporate Social Responsibility (CSR) and Good Corporate Governance (GCG) on corporate value. Firm size, leverage and profitability are used as control variables. Tests were conducted on 32 banking sector companies listed on the Indonesia Stock Exchange during the period 2015-2017 using purposive sampling technique. Data analysis using multiple linear regression. The results showed that GCG had a positive and significant effect on firm value, but CSR disclosure had no effect on company value. Leverage and profitability as control variables have a significant effect on firm value, while firm size does not affect firm value. The results of this study imply that good corporate governance plays a role in creating an increase in corporate value. On the other hand, the concern and involvement of companies in social investment such as CSR will provide the legitimacy of the company to operate so that it can obtain stakeholder support to ensure the longterm survival of the company.
\end{abstract}

Keywords: corporate value, corporate social responsibility (CSR), good corporate governance (GCG), firm size, leverage, profitability.

(C)2019 FEB UNRAM. All rights reserved 


\section{Pendahuluan}

Perbankan merupakan komponen penting dalam struktur ekonomi suatu negara. Meningkatnya kinerja perusahaan perbankan di suatu negara dapat dijadikan tolak ukur kemajuan suatu negara. Semakin maju suatu negara, maka semakin besar peranan perbankan dan semakin dibutuhkan baik oleh pemerintah maupun masyarakat (Nurcholis, 2013). Otoritas Jasa Keuangan (OJK) menggunakan laporan keuangan sebagai salah satu dasar dalam penentuan status kesehatan suatu Bank. Bank tetap harus menjaga tingkat kesehatan dan meningkatkan kinerjanya demi menjaga kepercayaan masyarakat. Untuk menjadi go public perusahaan harus sehat dan secara perlahan mendapatkan keuntungan setiap tahunnya (Lisyanti dan Ukhriyawati, 2017), tidak terkecuali perbankan.

Persepsi investor dipengaruhi oleh nilai perusahaan karena nilai perusahaan akan menunjukkan kinerja perusahaan dan harga saham perusahaan tersebut. Namun nilai perusahaan sejumlah bank pada beberapa tahun terakhir mengalami penurunan tercermin dari nilai sahamnya, sebagai contoh Bank Mandiri (Persero) Tbk pada tahun 2014 memiliki nilai perusahaan sebesar 2,46 menurun dari sebelumnya menjadi 1,81 pada tahun 2015 dan pada tahun 2016 mengalami penuruan dari dua tahun sebelumnya menjadi 1,7. Pada Bank Negara Indonesia (Persero) Tbk pada tahun 2014 memiliki nilai perusahaan sebesar 1,97 menurun dari sebelumnya menjadi 1,33 pada tahun 2015 dan pada tahun 2016 mengalami penurunan dari dua tahun sebelumnya menjadi 1,14. Dan yang terakhir pada PT Bank Central Asia Tbk pada tahun 2014 memiliki nilai perusahaan sebesar 4,21 menurun dari sebelumnya menjadi 4,17 pada tahun 2015 dan pada tahun 2016 mengalami penurunan dari dua tahun sebelumnya menjadi 3,24 (Ycharts, 2018).

Studi terdahulu mengungkap bahwa tinggi rendahnya nilai suatu perusahaan dapat dipengaruhi oleh pengungkapan Corporate Social Responsibility (CSR) dan Good Corporate Governance (GCG). Untuk dapat tumbuh secara berkelnajutan, perusahaan tidak hanya bertanggungjawab dalam hal keuangan saja, tetapi juga terhadap masalah sosial dan lingkungan sekitar perusahaan. Selain itu di Indonesia CSR diatur dalam suatu peraturan yang bersifat wajib untuk dilaksanakan sesuai dalam pasal 74 UndangUndang Nomor 40 tahun 2007 bahwa perseroan yang menjalankan kegiatan usahanya di bidang dan/atau berkaitan dengan sumber daya alam wajib melaksanakan tanggung jawab sosial dan lingkungan. Meskipun CSR diwajibkan oleh Undang-Undang nomor 40 tahun 2007 tersebut bagi perusahaan yang ekstraktif, namun juga dilakukan oleh perusahaan fasilitatif seperti perbankan, karena CSR yang dilaksanakan oleh perusahaan memberikan manfaat bagi perusahaan.

Didalam laporan tahunan perbankan pengungkapan mengenai CSR bukanlah merupakan kewajiban didalam pelaporan, akan tetapi merupakan pengungkapan sukarela (voluntary disclosure). Oleh sebab itu diperlukan pengawasan dan pengendalian sendiri oleh pemilik saham dan dewan komisaris dalam suatu tata kelola perusahaan atau Good Corporate Governance (GCG). Penerapan GCG di Indonesia terbilang masih lemah. Peringkat Corporate Governance pada Negara-negara di Asia Tenggara yang dilakukan oleh Asean Capital Markets Forum dan Asia Development Bank pada tahun 2014 Indonesia berada pada posisi peringkat ke lima setelah Thailand, Malaysia, Singapura, dan Philipina. Beberapa kasus akibat lemahnya penerapan tata kelola perusahaan yang baik di Indonesia dapat dilihat dari kasus fraud di Bank Mandiri (Persero) Tbk yang melibatkan pegawai Bank Mandiri melakukan pembobolan Bank Mandiri dengan kerugian sebesar Rp 1,4 triliun (Tjandra, 2018). Pada Bank Negara Indonesia (Persero) Tbk juga melibatkan pegawai Bank BNI membawa kabur uang milik Bank BNI yang merupakan uang yang dikumpulkan dari beberapa kantor layanan 
nasabah Bank BNI dengan kerugian sebesar Rp 7,7 Miliar (Buol, 2014). Dan kasus fraud terjadi juga pada PT Bank Central Asia Tbk yang juga melibatkan pegawai Bank BCA melakukan pembobolan uang 200 nasabah lewat anjungan tunai mandiri (ATM) dengan kerugian sebesar Rp 5 miliar (ape/nwk, 2010).

Peraturan Otoritas Jasa Keuangan (2016) mengemukakan bahwa tata kelola perbankan yang baik adalah suatu tata cara pengelolaan bank yang menerapkan prinsipprinsip keterbukaan (transparency), akuntabilitas (accountability), pertanggungjawaban (responsibility), independensi (independency), dan kewajaran (fairness). Penerapan mekanisme Good Corporate Governance dapat meningkatkan kualitas laporan keuangan dari suatu perusahaan. Laporan keuangan yang berkualitas harus mampu menyediakan informasi yang relevan dan berguna dalam pengambilan keputusan ekonomi maupun keputusan investasi bagi para investor, serta menganut prinsip-prinsip akuntansi yang berlaku umum dan bebas dari pemalsuan serta kecurangan (Kusumaningtyas dan Andayani, 2015).

Diantara kajian penelitian sebelumnya yang menguji tentang pengaruh pengungkapan CSR dan GCG terhadap nilai perusahaan (Debby dkk., 2014; Stacia dan Juniarti, 2015) faktor spesifik industri atau sektor belum dipertimbangkan. Oleh karena itu penelitian ini memperluas pengujian dengan menginternalisasikan variabel kontrol ukuran perusahaan, leverage dan profitabilitas sebagai kebaruan. Penelitian ini juga menggunakan nilai komposit self assessment corporate governance untuk mengukur GCG bank serta indikator GRI G4 untuk mengukur pengungkapan CSR. Dengan demikian tujuan penelitian ini adalah menguji pengaruh pengungkapan Corporate Social Responsibility (CSR) dan Good Corporate Governance (GCG) terhadap nilai perusahaan. Hasil penelitian ini memberikan kontribusi terhadap tata kelola perusahaan yang mampu berperan dalam menciptakan peningkatan nilai perusahaan dan pada saat yang sama juga memiliki kepedulian terhadap tanggung jawab sosial sehingga dapat memberikan legitimasi perusahaan dalam beroperasi dan memperoleh dukungan dari para pemangku kepentingan untuk menjamin kelangsungan hidup perusahaan dalam jangka panjang.

\section{Kerangka Teoretis Dan Pengembangan Hipotesis Kerangka Teoretis}

Signaling Theory menjelaskan bagaimana seharusnya sinyal-sinyal keberhasilan atau kegagalan manajemen (agent) disampaikan kepada pemilik (principal). Teori ini menjelaskan mengapa perusahaan mempunyai dorongan untuk melaporkan informasi secara sukarela ke pasar modal. Pelaporan informasi oleh manajemen bertujuan untuk mempertahankan investor yang tertarik kepada perusahaan. Informasi keuangan yang disampaikan perusahaan bertujuan untuk mengurangi asimetri informasi antara perusahaan dengan pihak luar perusahaan.

Terjadinya asimetri informasi dikarenakan pihak manajemen perusahaan lebih banyak mengetahui mengenai prospek perusahaan dibandingkan pihak luar perusahaan. Agar tidak terjadinya asimetri informasi ini perusahaan harus memberikan informasi sebagai sinyal kepada pihak investor. Asimetri informasi perlu diminimalkan dengan memberikan sinyal kepada pihak luar perusahaan salah satunya berupa informasi keuangan yang dapat dipercaya dan akan mengurangi ketidakpastian mengenai prospek perusahaan yang akan datang, sehingga perusahaan yang go public dapat menginformasikan keadaan perusahaan secara transparan kepada investor. Pengungkapan CSR dan informasi GCG merupakan salah satu upaya perusahaan untuk memberikan sinyal kepada stakeholder.

Laporan tahunan adalah salah satu jenis laporan yang dikeluarkan oleh perusahaan sebagai informasi yang dijadikan sinyal bagi pihak luar, dan yang terutama bagi pihak 
investor. Dalam laporan tahunan informasi yang diungkapkan berupa laporan keuangan dan informasi yang tidak berkaitan dengan laporan keuangan. Perusahaan dapat meningkatkan nilai perusahaan dengan mengurangi asimetri informasi. Laporan keuangan yang menunjukkan angka laba perusahaan yang tinggi dapat dijadikan sinyal oleh investor sebagai tolak ukur bahwa kinerja perusahaan baik yang meningkatkan kepercayaan investor sehingga investor tertarik untuk berinvestasi dalam perusahaan tersebut, dengan demikian akan berdampak pada peningkatan nilai perusahaan yang tercermin dari kenaikan harga saham perusahaan.

Perusahaan akan terus berlanjut keberadaannya jika masyarakat menyadari bahwa perusahaan beroperasi untuk sistem nilai yang sepadan dengan sistem nilai masyarakat itu sendiri. Teori Legitimasi menganjurkan perusahaan untuk meyakinkan bahwa aktivitas dan kinerjanya dapat diterima oleh masyarakat. Perusahaan menggunakan laporan tahunan untuk menggambarkan kesan tanggung jawab lingkungan dalam mengungkapkan aktivitas CSR perusahaan semaksimal mungkin agar aktivitas perusahaan dapat diterima oleh masyarakat. Legitimasi memiliki manfaat untuk mendukung keberlangsungan hidup suatu perusahaan dengan operasi perusahaan harus kongruen dengan harapan masyarakat (O’Donovan, 2002 dalam Pujana, 2016). Praktikpraktik tanggung jawab sosial dan pengungkapan sosial yang dilakukan oleh perusahaan dapat dipandang sebagai suatu usaha untuk memenuhi harapan-harapan masyarakat terhadap perusahaan. Perusahaan selalu berusaha menyelaraskan diri dengan normanorma yang ada di dalam masyarakat dan mengantisipasi terjadinya kesenjangan legitimasi.

\section{Nilai Perusahaan}

Nilai perusahaan (value of the firm) merupakan kondisi tertentu yang telah dicapai oleh suatu perusahaan sebagai gambaran dari kepercayaan masyarakat terhadap perusahaan setelah melalui suatu proses kegiatan selama beberapa tahun, yaitu sejak perusahaan tersebut didirikan sampai dengan saat ini. Meningkatnya nilai perusahaan adalah sebuah prestasi, yang sesuai dengan keinginan para pemiliknya, karena dengan meningkatnya nilai perusahaan maka kesejahteraan para pemilik juga akan meningkat (Oktrivina, 2016). Nilai perusahaan dapat menggambarkan keadaan yang dimiliki suatu perusahaan. Jika nilai perusahaan baik maka perusahaan akan dipandang baik oleh calon investor. Nilai perusahaan dalam pandangan investor adalah penilaian terhadap tingkat atas keberhasilan perusahaan yang berkaitan dengan harga saham perusahaan yang dimiliki. Harga saham yang dimaksud adalah harga saham pada saat penutupan (closing price), dan harga yang terjadi ketika saham tersebut diperdagangkan di bursa. Harga saham yang tinggi akan membuat nilai perusahaan tinggi, dan hal tersebut juga akan meningkatkan kepercayaan pasar terhadap kinerja yang dilakukan perusahaan dan prospek perusahaan di masa depan.

Nilai perusahaan sering kali di proksikan dengan price to book value. Price to book value dapat diartikan sebagai perbandingan antara harga saham dengan nilai buku per lembar saham. Dengan adanya price to book value bagi investor akan membuat investor bisa menentukan strategi dalam melakukan investasi di pasar modal melalui price to book value, investor dapat memprediksi saham yang harga rendah maupun harganya tinggi. Price to book value menggambarkan seberapa besar pasar dalam menghargai nilai buku saham suatu perusahaan. Perusahaan yang berjalan dengan baik, umumnya memiliki rasio price to book value di atas satu, yang mencerminkan bahwa nilai pasar saham lebih besar dari nilai bukunya. Price to book value yang tinggi mencerminkan tingkat kemakmuran bagi pemegang saham merupakan tujuan utama perusahaan. 


\section{Pengungkapan Corporate Social Responsibility}

Word Business Council for Sustainable Development (WBCSD) mendefinisikan CSR sebagai "komitmen bisnis untuk berkontribusi terhadap pembangunan ekonomi yang berkelanjutan, bekerja dengan karyawan, keluarga mereka dan masyarakat lokal" (Mardikanto, 2014: 93). Corporate Social Responsibility adalah sebuah konsep dimana perusahaan mengintegrasikan kepedulian sosial dan lingkungan dalam operasi bisnis dan dalam interaksi dengan para pemangku kepentingan secara sukarela yang semakin menyadarkan bahwa perilaku bertanggung jawab mengarah pada keberhasilan bisnis yang berkelanjutan. Mardikanto (2014: 132-141) menjelaskan kemanfaatan Corporate Social Responsibility tidak hanya dirasakan oleh pemerintah dan korporasi, tetapi juga oleh masyarakat. Dengan demikian CSR bermanfaat bagi masyarakat, korporasi, dan pemerintah. Bagi masyarakat CSR bermanfaat antara lain untuk peningkatan kualitas hidup masyarakat karena perusahaan melakukan aktivitas-aktivitas serta pembuatan kebijakan-kebijakan yang dapat meningkatkan kesejahteraan, kualitas hidup, dan kompetensi masyarakat diberbagai bidang. Manfaat CSR bagi pemerintah adalah cukup banyak memberikan kontribusi kepada pemerintah, dalam bentuk terciptanya hubungan antara pemerintah dan perusahaan dalam mengatasi berbagai masalah sosial, seperti kemiskinan, rendahnya kualitas pendidikan, minimnya akses kesehatan dan lain sebagainya.

Pengungkapan CSR adalah cara yang dilakukan oleh perusahaan untuk mengkomunikasikan aktivitas tanggung jawab sosial yang telah dilakukan berupa informasi ke dalam laporan tahunan perusahaan untuk ditujukan kepada masyarakat dan pihak yang berkepentingan. Pengungkapan CSR oleh perusahaan dalam laporan tahunan diharapkan mampu memenuhi kebutuhan informasi bagi stakeholders dan publik sehingga perusahaan akan mendapatkan dukungan dalam usahanya mencapai tujuan perusahaan (Sari, dkk. 2016). Standar pengungkapan CSR yang berkembang di Indonesia merujuk pada standar yang diterapkan GRI (Global Reporting Intiative). Standar GRI dipilih karena lebih memfokuskan pada standar pengungkapan sebagai kinerja ekonomi, sosial, dan lingkungan perusahaan dengan tujuan untuk meningkatkan kualitas dan pemanfaatan sustainability reporting (www.globalreporting.org). Saat ini standar GRI-G4 telah banyak digunakan oleh perusahaan di Indonesia. GRI-G4 menyediakan kerangka kerja yang relevan secara global untuk mendukung pendekatan yang terstandarisasi dalam pelaporan yang mendorong tingkat transparansi dan konsistensi yang diperlukan untuk membuat informasi yang disampaikan menjadi berguna dan dapat dipercaya oleh pasar dan masyarakat. GRI G4 merupakan pedoman penyusunan laporan keberlanjutan yang terdiri dari dua pengungkapan yaitu umum dan spesifik. Pengungkapan umum memilik tujuh kategori, yang tediri dari strategi dan analisis, profil organisasi, identifikasi aspek material dan boundary, hubungan dengan pemangku kepentingan, profil laporan, tata kelola, serta etika dan integritas. Pengungkapan spesifik memiliki tiga kategori yang terdiri dari ekonomi, lingkungan, dan sosial.

\section{Good Corporate Governance}

Good Corporate Governance (GCG) merupakan serangkaian mekanisme dalam suatu struktur pengelolaan perusahaan yang menetapkan distribusi hak dan tanggung jawab diantara berbagai partisipan di dalam perusahaan, termasuk para pemegang saham, dewan komisaris, dewan direksi, manajer, karyawan dan pihak-pihak berkepentingan lainnya. GCG penting diterapkan dalam perbankan berkaitan dengan kepercayaan yang diberikan dalam menghimpun dana masyarakat sehingga perusahaan harus bertindak untuk kepentingan terbaik bagi semua pemangku kepentingan. Dalam upaya mendukung sektor ekonomi nasional dan daerah melalui penguatan sektor 
perbankan, Bank Indonesia pada tahun 2004 telah meluncurkan program Arsitektur Perbankan Indonesia (API) untuk dilaksanakan dalam kurun waktu lima sampai sepuluh tahun ke depan. Arsitektur Perbankan Indonesia memiliki visi yang dijabarkan kedalam enam pilar. Salah satu dari enam pilar tersebut yaitu menciptakan GCG dalam rangka memperkuat kondisi internal perbankan nasional. Untuk menghadapi risiko bisnis bank yang semakin meningkat maka penerapan tata kelola perusahaan yang baik pada perbankan diperlukan untuk dapat meningkatkan kinerja operasional bank.

Seiring dengan tuntutan penerapan GCG pada sektor perbankan, maka pada tahun 2006 Bank Indonesia menggagas peraturan yang secara khusus mengatur mengenai ketentuan pelaksanaan GCG di Bank Umum. Peraturan yang dimaksud adalah Peraturan Bank Indonesia Nomor 8/4/PBI/2006 tanggal 30 Januari 2006 tentang Pelaksanaan Good Corporate Governance Bagi Bank Umum yang kembali disempurnakan melalui PBI No. 8/14/PBI/2006 tanggal 5 Oktober 2006 tentang Perubahan Atas PBI No. 8/4/PBI/2006 tentang Pelaksanaan Good Corporate Governance Bagi Bank Umum. Dalam Peraturan Otoritas Jasa Keuangan nomor 55/POJK.03/2016 tentang penerapan tata kelola bagi bank umum, tata kelola yang baik adalah suatu tata cara pengelolaan Bank yang senantiasa berlandaskan pada lima prinsip dasar. Pertama, keterbukaan (transparency), yaitu keterbukaan dalam mengemukakan informasi yang material dan relevan serta keterbukaan dalam melaksanakan proses pengambilan keputusan. Kedua, akuntabilitas (accountability) yaitu kejelasan fungsi dan pelaksanaan pertanggungjawaban organ bank sehingga pengelolaannya berjalan secara efektif. Ketiga, pertanggungjawaban (responsibility) yaitu kesesuaian pengelolaan bank dengan peraturan perundang-undangan dan prinsip-prinsip pengelolaan bank yang sehat. Keempat, independensi (independency) yaitu pengelolaan bank secara professional tidak ada pengaruh atau tekanan dari pihak manapun. Kelima, kewajaran (fairnees) yaitu keadilan dan kesetaraan dalam memenuhi hak-hak para pemangku kepentingan yang timbul berdasarkan perjanjian dan peraturan perundang-undangan.

Dalam Surat Edaran Otoritas Jasa Keuangan Nomor 13/SEOJK.03/2017 tentang penerapan tata kelola bagi bank umum, dalam rangka memastikan penerapan lima prinsip dasar tata kelola yang baik, bank harus melakukan penilaian sendiri (selfassessment) secara berkala. Dalam melakukan penilaian sendiri (self-assessment) bank terlebih dahulu memahami tujuan penilaian penerapan tata kelola yang mencakup tiga aspek governance yaitu governance structure. governance process, dan governance outcome, serta kriteria atau indikator pada setiap faktor penilaian. Penilaian governance structure bertujuan untuk menilai kecukupan struktur dan infrastruktur tata kelola bank agar proses penerapan prinsip tata kelola yang baik menghasilkan outcome yang sesuai dengan harapan pemangku kepentingan bank. Penilaian governance process bertujuan untuk menilai efektivitas proses penerapan prinsip tata kelola yang baik yang didukung oleh kecukupan struktur dan infrastruktur tata kelola bank sehingga menghasilkan outcome yang sesuai dengan harapan pemangku kepentingan bank. Penilaian governance outcome bertujuan untuk menilai kualitas outcome yang memenuhi harapan pemangku kepentingan bank yang merupakan hasil proses penerapan prinsip tata kelola yang baik serta didukung oleh kecukupan struktur dan infrastruktur tata kelola bank (Surat Edaran Otoritas Jasa Keuangan, 2017).

Dalam upaya perbaikan dan peningkatan kualitas penerapan tata kelola, bank secara berkala melakukan penilaian sendiri (self-assessment) secara komprehensif terhadap kecukupan penerapan tata kelola sehingga bank dapat segera menetapkan rencana tindak (action plan), yang meliputi tindakan korektif (corrective action) yang diperlukan dalam hal masih terdapat kekurangan dalam penerapan tata kelola. Penetapan peringkat faktor tata kelola dikategorikan ke dalam 5 (lima) peringkat yaitu 
peringkat 1 , peringkat 2 , peringkat 3 , peringkat 4 , dan peringkat 5 . Urutan peringkat faktor tata kelola yang lebih kecil mencerminkan penerapan tata kelola yang lebih baik (Surat Edaran Otoritas Jasa Keuangan, 2017). Perbankan diwajibkan menyampaikan laporan pelaksanaan tata kelola kepada Otoritas Jasa Keuangan dan pemegang saham bank paling lambat 4 bulan setelah tahun buku berakhir. Dan laporan pelaksanaan tata kelola wajib dipublikasikan pada website bank. Apabila perusahaan perbankan belum menyampaikan dan/atau mempublikasikan laporan pelaksanaan tata kelola melampui satu bulan sejak 4 bulan setelah tahun buku berakhir maka perusahaan perbankan dianggap tidak menyampaikan laporan pelaksanaan tata kelola dan/atau mempublikasikan laporan pelaksanaan tata kelola pada website bank (Peraturan Otoritas Jasa Keuangan, 2016).

\section{Pengembangan Hipotesis}

Dalam Legitimacy Theory, legitimasi dianggap menyamakan persepsi atau asumsi bahwa tindakan yang dilakukan oleh suatu entitas merupakan tindakan yang diinginkan, pantas atau sesuai dengan sistem norma, nilai, kepercayaan dan definisi yang dikembangkan secara sosial (Suchman,1995). Praktik-praktik tanggung jawab sosial dan pengungkapan sosial yang dilakukan oleh perusahaan dapat dipandang sebagai suatu usaha untuk memenuhi harapan masyarakat terhadap perusahaan. Corporate Social Responsibility (CSR) adalah gagasan yang membuat perusahaan tidak hanya bertanggungjawab dalam hal keuangan saja, tetapi juga terhadap masalah sosial dan lingkungan sekitar perusahaan agar perusahaan dapat tumbuh secara berkelanjutan. Perusahaan akan terus tumbuh berkelanjutan jika masyarakat menyadari bahwa perusahaan beroperasi untuk sistem nilai yang sepadan dengan sistem nilai masyarakat itu sendiri.

Perusahaan menggunakan laporan tahunan untuk menggambarkan kesan tanggung jawab sosial dan lingkungan dalam mengungkapkan aktivitas CSR perusahaan semaksimal mungkin agar aktivitas perusahaan dapat diterima oleh masyarakat. Pengungkapan informasi-informasi di dalam laporan tahunan perusahaan dapat memperkuat legitimasinya yaitu dengan menyebutkan penghargaan-penghargaan lingkungan yang telah diraih. Dengan adanya penerimaan dari masyarakat diharapkan dapat meningkatkan nilai perusahaan sehinggga dapat meningkatkan laba perusahaan dan dapat meningkatkan reputasi perusahaan di masyarakat. Pernyataan tersebut didukung dengan hasil penelitian Fitri dan Herwiyanti (2013) serta Tjipto dan Juniarti (2016) yang menyatakan bahwa pengungkapan CSR berpengaruh terhadap nilai perusahaan yang mengargumentasikan bahwa perusahaan yang menerapkan dan mengungkapkan CSR menunjukkan bahwa perusahaan tersebut peduli terhadap masyarakat dan lingkungannya. Hal ini merupakan bentuk keberpihakan perusahaan kepada masyarakat sehingga dapat meningkatkan harga saham perusahaan yang selanjutnya akan meningkatkan nilai perusahaan karena hal tersebut dapat mendorong investor dalam melakukan pengambilan keputusan investasi yang berdampak pada peningkatan nilai perusahaan. Berdasarkan argumentasi di atas maka dapat dirumuskan hipotesis sebagai berikut:

$\mathrm{H}_{1}$ : Pengungkapan Corporate Social Responsibility berpengaruh terhadap nilai perusahaan

Tata kelola perusahaan sebagai sistem yang dipergunakan untuk mengarahkan dan mengelola kegiatan perusahaan. Sistem tersebut mempunya pengaruh yang besar dalam menentukan sasaran usaha maupun upaya dalam mencapai sasaran. Tata kelola perusahaan juga mempunyai pengaruh dalam upaya mencapai kinerja bisnis yang optimal serta dalam analisis dan pengendalian resiko bisnis yang dihadapi perusahaan. 
Tata kelola korporasi yang tidak sehat dapat menimbulkan godaan penyalahgunaan wewenang seperti konflik kepentingan antara manajer (agent) dengan pemegang saham (pemilik) yaitu manajer melakukan kecurangan dengan melakukan manajemen laba untuk kepentingan diri sendiri padahal hal tersebut menyebabkan menurunnya nilai perusahaan. Manajemen perusahaan yang lemah, etika bisnis yang buruk, dan moral manajemen kurang baik juga dapat merugikan stakeholders, terutama para pemegang saham, kreditur, dan karyawan.

Dengan diterapkannya prinsip-prinsip corporate governance yaitu prinsip keterbukaan, prinsip akuntabilitas, prinsip pertanggungjawaban, prinsip independensi, dan prinsip kewajaran di dalam perusahaan maka corporate governance dapat mengatasi dan meminimalkan adanya berbagai macam konflik kepentingan, sehingga hal tersebut dapat membuat kegiatan operasional perusahaan dapat berjalan dengan optimal dan meningkatkan nilai perusahaan. Selain itu perusahaan yang melaksanakan praktik corporate governance yang baik akan memberikan laporan keuangan yang berkualitas kepada investor sehingga kredibilitas laporan keuangan tersebut meningkat. Kredibilitas laporan keuangan yang meningkat akan meningkatkan kepercayaan investor sehingga harga saham juga meningkat. Oleh karena itu, dapat diprediksi bahwa semakin baik praktik corporate governance yang diterapkan oleh suatu perusahaan semakin tinggi nilai perusahaan. Studi empiris yang dilakukan oleh Kebon dan Suryanawa (2017) serta Retno dan Priantinah (2012) menemukan bahwa good corporate governance berpengaruh pada nilai perusahaan. Hal ini disebabkan karena perusahaan yang memiliki good corporate governance yang baik mencerminkan manajer mampu mengelola perusahaan dengan baik sehingga investor yakin menanamkan sahamnya di perusahaan tersebut yang selanjutnya berdampak pada nilai perusahaan. Berdasarkan argumentasi di atas maka dapat dirumuskan hipotesis sebagai berikut :

$\mathrm{H}_{2}$ : Good Corporate Governance berpengaruh terhadap nilai perusahaan

\section{Metode Penelitian}

Penelitian ini dari pendekatannya merupakan jenis penelitian asosiatif kausalitas, yaitu menguji pengaruh variabel independen terhadap variabel dependen. Penelitian dilakukan pada perusahaan perbankan yang terdaftar di Bursa Efek Indonesia dengan menggunakan data dari laporan tahunan dan laporan keberlanjutan pada website resmi masing-masing bank pada tahun 2015-2017. Populasi dalam penelitian ini adalah perusahaan perbankan yang terdaftar di Bursa Efek Indonesia dari tahun 2015-2017. Metode pemilihan sampel yang digunakan adalah purposive sampling dengan jumlah total sampel adalah 32 bank yang melakukan pengungkapan CSR.

Variabel dependen dalam penelitian ini adalah nilai perusahaan, sedangkan variabel independennya adalah pengungkapan Corporate Social Responsibility (CSR) dan Good Corporate Governance (GCG). Variabel ukuran perusahaan, leverage dan profitabilitas digunakan sebagai variabel kontrol. Definisi konseptual dan operasional masing-masing variabel disajikan sebagai berikut :

1. Nilai Perusahaan merupakan kinerja perusahan yang dicerminkan oleh harga saham. Price to book value menggambarkan semakin tinggi rasio tersebut maka pasar akan percaya pada prospek perusahaan. Secara sistematis Price to book value (PBV) dapat dihitung dengan rumus sebagai berikut:

$$
\text { Price to Book Value }(P B V)=\frac{\text { Harga saham } t}{\text { Nilai Buku per Saham } t}
$$


2. Pengungkapan Corporate Social Responsibility (CSR). Data-data yang digunakan untuk mengukur CSR dengan GRI G4 dapat diperoleh dari laporan CSR dan laporan tahunan yang dikeluarkan masing-masing perusahaan. Pengungkapan CSR diukur dengan menggunakan indikator GRI G4, dengan rumus sebagai berikut:

$$
C S R=\frac{\text { Total item yang diungkapkan }}{137 \text { item }}
$$

3. Good corporate governance (GCG) dalam penelitian ini diukur dengan menggunakan nilai komposit self assessment GCG menurut Surat Edaran Otoritas Jasa Keuangan. Self assessment GCG Perbankan diantaranya yaitu peringkat 1 dengan predikat sangat baik, peringkat 2 dengan predikat baik, peringkat 3 dengan predikat cukup, peringkat 4 dengan predikat kurang baik, peringkat 5 dengan predikat tidak baik.

4. Variabel kontrol

a. Firm Size. Secara umum, ukuran perusahaan diukur dengan besarnya total asset yang dimiliki perusahaan karena nilai total asset umumnya sangat besar dibandingkan variabel keuangan lainnya (Rahmawati, dkk. 2015). Rumus ukuran perusahaan yaitu:

$$
\text { Ukuran perusahaan }=\operatorname{Ln}(\text { Total Aset })
$$

b. Leverage. Tingginya rasio leverage terhadap aset menunjukkan semakin banyak aktiva didanai oleh hutang pada pihak luar, dan menunjukkan resiko perusahaan dalam pelunasannya, sehingga menyebabkan intensif manajemen untuk merekayasa kinerja untuk menjaga kepercayaan dari pihak eksternal. Perhitungan leverage adalah sebagai berikut:

$$
\text { DAR }=\frac{\text { Total hutang }}{\text { Total Aktiva }}
$$

c. Profitabilitas. ROA (Return On Assest) menggambarkan semakin tinggi tingkat profit yang dicapai bank, dengan demikian posisi bank semakin baik dalam mengelola atau menggunakan assetnya. Peningkatan ROA perbankan memberikan informasi prospek perusahaan yang baik sehingga dapat memicu investor untuk membeli saham, seiring dengan peningkatan permintaan saham akan menyebabkan nilai perusahaan juga meningkat. ROA dihitung dengan rumus berikut ini:

$$
\mathrm{ROA}=\frac{\text { Laba setelah pajak }}{\text { Total Aktiva }}
$$

Prosedur analisis data dalam penelitian ini menggunakan regresi linier berganda, setelah sebelumnya dilakukan pengujian asumsi klasik. Analisis regresi linier berganda (linear regression analysis) digunakan dalam penelitian ini untuk menguji pengaruh variabel independen pengungkapan Corporate Social Responsibility (CSR) dan Good Corporate Governance (GCG) terhadap variabel dependen (nilai perusahaan) serta melibatkan tiga variabel control (Firm Size, Leverage, dan Profitabilitas). Hipotesis 1 
dan 2 diuji dengan menggunakan pengujian pengaruh langsung. Berikut ini adalah model persamaan matematis yang diuji :

$$
\begin{array}{ll}
\mathrm{NP}=\alpha+\beta_{1} \mathrm{CSR}+\beta_{2} \mathrm{GCG}+\beta_{3} \text { Firm Size }+\beta_{4} \text { Leverage }+\beta_{5} \text { Profitability }+e \\
\begin{array}{ll}
\text { Keterangan: } & \\
\mathrm{NP} & =\text { Nilai Perusahaan } \\
\alpha & =\text { Konstanta } \\
\beta & =\text { Koefisien Regresi } \\
\mathrm{CSR} & =\text { Corporate Social Responsibility }(\mathrm{CSR}) \\
\mathrm{GCG} & =\text { Good Corporate Governance }(\mathrm{GCG}) \\
\text { Firm Size } & =\text { Ukuran Perusahaan } \\
\text { Leverage } & =\text { Leverage } \\
\text { Profitability } & =\text { Profitability } \\
\text { E } & =\text { error }
\end{array}
\end{array}
$$

Secara grafis model penelitian disajikan pada gambar 1 berikut ini:

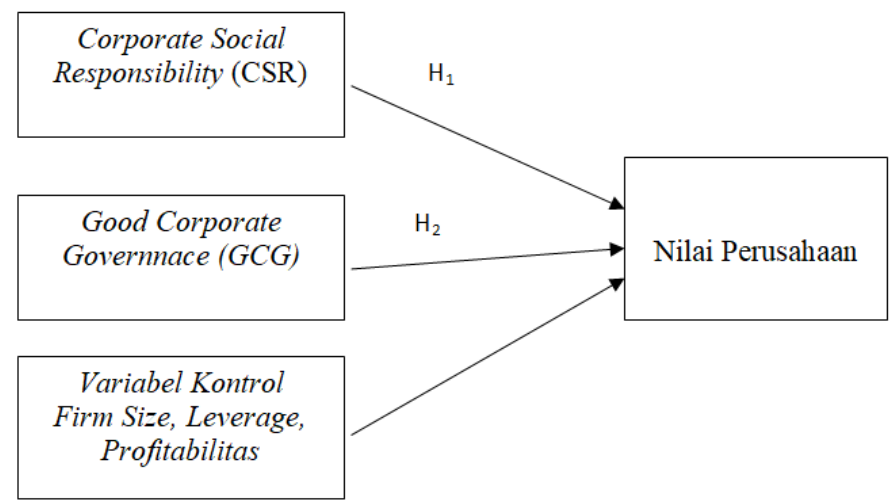

\section{Gambar 1. Model Penelitian}

\section{Hasil dan Pembahasan}

Bagian hasil dan pembahasan menjelaskan hasil pengujian statistik dan interpretasi terhadap hasilnya. Uji asumsi klasik yang digunakan dalam penelitian ini meliputi uji normalitas, uji multikolonieritas, uji heteroskedasitas, dan uji autokorelasi. Tabel hasil uji asumsi klasik tersebut dapat dilihat pada tabel 1 berikut ini:

Tabel 1. Uji Asumsi Klasik

\begin{tabular}{lcccccc}
\hline Parameter yang diuji & \multicolumn{2}{c}{$\begin{array}{c}\text { Uji } \\
\text { Normalitas }\end{array}$} & \multicolumn{2}{c}{$\begin{array}{c}\text { Uji } \\
\text { Multikolonieritas }\end{array}$} & $\begin{array}{c}\text { Uji } \\
\text { Heteroskedastisitas }\end{array}$ & $\begin{array}{c}\text { Uji } \\
\text { Autokorelasi }\end{array}$ \\
\hline & $\mathbf{Z}$ & $\mathbf{P}$ & Tolerance & VIF & Sig & DW \\
\hline Unstandardized Residual & 0,060 & 0,200 & & & & \\
CSR & & & 0,672 & 1,487 & 0,603 & \\
GCG & & & 0,660 & 1,515 & 0,268 & \\
SIZE & & 0,447 & 2,238 & 0,052 & \\
LEVERAGE & & 0,966 & 1,035 & 0,067 & \\
PROFITABILITAS & & 0,616 & 1,624 & 0,928 & \\
Durbin Watson & & & & & & 2,049 \\
\hline
\end{tabular}


Tingkat signifikansi pada uji normalitas sebesar 0,200 yang lebih besar dari 0,05 yang berarti bahwa data dalam penelitian ini terdistribusi normal. Nilai tolerance $>0,10$ dan VIF $<10$ sehingga dapat disimpulkan bahwa variabel bebas tidak saling berkorelasi secara signifikan (bebas multikolonieritas). Tingkat signifikansi variabel tersebut di atas $5 \%$ atau 0.05 , oleh karena itu dapat disimpulkan bahwa model regresi tersebut terbebas dari masalah heteroskedastisitas. Dengan $\mathrm{k}=5$ dan $\mathrm{n}=96$ pada $\alpha=0,05$ diperoleh $\mathrm{du}=$ 1,597 sehingga nilai DW 2,049 terletak diantara du dan 4-du yang merupakan daerah bebas autokorelasi. Dengan demikan persyaratan uji asumsi klasik telah terpenuhi sehingga dapat dilanjutkan pada pengujian regresi linier berganda. Hasil pengujian analisis regresi linier berganda disajikan pada tabel 2 .

Tabel 2. Uji Regresi Linier Berganda

\begin{tabular}{lrrc}
$\begin{array}{l}\text { Signifikansi Parameter Individual } \\
\text { (t statistik) }\end{array}$ & B & Signifikansi & Kesimpulan \\
& & & \\
\hline CSR & 0,084 & 0,438 & Nonsignifikan \\
GCG & $-0,363$ & 0,001 & Signifikan \\
SIZE & $-0,210$ & 0,116 & Nonsignifikan \\
LEVERAGE & $-0,192$ & 0,036 & Signifikan \\
PROFITABILITAS & 0,378 & 0,001 & Signifikan \\
Uji Signifikansi Model (statistik F) & & & \\
Nilai F & & & \\
Sig. & & & \\
Uji Kemampuan Prediksi Model: & & & \\
R Square & & & \\
Adjusted R Square & & & \\
Variabel Dependen: Nilai Perusahaan & & & \\
\hline
\end{tabular}

Nilai probabilitas $\mathrm{F}$ sebesar 0,000 yang lebih kecil dari $\alpha=0,05$ yang berarti bahwa secara simultan variabel bebas dalam model dapat mempengaruhi variabel terikat secara signifikan. Koefisien determinasi dengan parameter Adjusted $\mathrm{R}^{2}$ sebesar 0,310 yang berarti bahwa $31 \%$ variasi nilai perusahaan dapat dijelaskan oleh variasi dari lima variabel independen, sedangkan $69 \%$ dijelaskan oleh faktor lain. Hasil pengujian signifikansi parameter individual atau uji t menunjukkan hanya variabel GCG yang signifikan mempengaruhi nilai perusahaan dengan nilai signifikansi dibawah 0,05 dengan arah koefisien positif, sedangkan variabel pengungkapan CSR tidak berpengaruh signifikan terhadap nilai perusahaan karena nilai signifikansi dibawah 0,05 . Hanya variabel kontrol leverage dan profitabilitas yang signifikan, sedangkan ukuran perusahaan tidak signifikan dalam mempengaruhi nilai perusahaan.

Berdasarkan uji statistik pada tabel 2 dapat dijelaskan bahwa secara parsial pengungkapan CSR berpengaruh positif tidak signifikan terhadap nilai perusahaan, hal ini dibuktikan dengan nilai standardized beta coefficients sebesar 0,084 dengan probabilitas signifikan sebesar 0,438. Nilai signifikansi 0,438 lebih besar dari 0,05. Apabila perusahaan memiliki kinerja sosial dan lingkungan yang baik, maka akan muncul kepercayaan dari investor sehingga direspon positif melalui peningkatan harga saham perusahaan. Dengan demikian akan meningkatkan nilai perusahaan (Fitri dan Herwiyanti, 2013). Namun dalam penelitian ini menemukan bahwa pengungkapan CSR tidak signifikan direspon oleh investor yang ditunjukkan dengan nilai signifikansi diatas 0,05 , hal ini menandakan bahwa perusahaan perbankan merupakan perusahaan yang 
fasilitatif dan tidak memiliki dampak lingkungan secara langsung. Sektor perbankan dalam mengungkapkan tanggung jawab sosial perusahaan tidak bersifat wajib melainkan bersifat sukarela. Hasil penelitian ini sejalan dengan penelitian yang dilakukan oleh Stacia dan Juniarti (2015) serta Fiadicha dan Hanny (2016) menyatakan bahwa pengungkapan CSR tidak berpengaruh terhadap nilai perusahaan.

Berdasarkan uji statistik pada tabel 2 dapat dijelaskan bahwa secara parsial GCG berpengaruh signifikan negatif terhadap nilai perusahaan, hal ini dibuktikan dengan nilai standardized beta coefficients sebesar -0,363 dengan probabilitas signifikan sebesar 0,001. Nilai signifikansi lebih kecil dari 0,05 dengan arah hubungan koefisien regresi negatif. Berpengaruh negatif artinya ada hubungan tidak searah antara GCG dan nilai perusahaan, namun pada penelitian ini GCG berpengaruh negatif memiliki arti bahwa semakin kecil nilai predikat GCG maka semakin baik penerapan self assessment corporate governance yang diterapkan bank. Semakin meningkat predikat GCG yang dilakukan bank maka akan berdampak positif terhadap nilai perusahaan. Dengan demikian perusahaan yang memiliki predikat GCG baik akan lebih dipercaya oleh investor sehingga berdampak pada nilai perusahaan. Temuan ini sejalan dengan argumentasi bahwa tumbuhnya kepercayaan investor kepada perusahaan, dinilai dapat meningkatkan jumlah investor yang masuk ke pasar modal untuk melakukan investasi atau membeli saham perusahaan, sehingga harga saham perusahaan akan menjadi naik, dan nilai perusahaan pun akan semakin tinggi (Pujana, 2016). Hasil penelitian ini konsisten dengan hasil penelitian Kebon dan Suryanawa (2017) serta Retno dan Priantinah (2012) menyatakan bahwa good corporate governance (GCG) berpengaruh terhadap nilai perusahaan.

Terkait hubungan antara variabel kontrol ukuran perusahaan terhadap nilai perusahaan menunjukkan bahwa berdasarkan uji statistisk pada tabel 2 dapat dijelaskan bahwa secara parsial ukuran perusahaan berpengaruh negatif tidak signifikan terhadap nilai perusahaan, hal ini dibuktikan dengan nilai standardized beta coefficients sebesar 0,210 dengan probabilitas signifikan sebesar 0,116. Nilai signifikansi 0,116 lebih besar dari 0,05 sehingga tidak signifikan mempengaruhi nilai perusahaan. Adanya hubungan negatif artinya bahwa besarnya ukuran perusahaan perbankan dengan nilai perusahaan memiliki arah yang berbeda dengan kata lain bahwa tidak selalu perusahaan dengan ukuran yang besar dapat meningkatkan nilai perusahaan. Seperti pada perusahaan perbankan yang memiliki total aset yang tinggi tidak mampu menarik investor untuk membeli saham perusahaannya. Kondisi ini mengindikasikan bahwa perusahaan perbankan yang lebih besar tidak bisa mendapatkan keuntungan dari produknya karena terjadinya kredit bermasalah dan kredit macet serta tingginya pembiayaan sehingga return yang didapatkan kecil. Hasil penelitian ini sejalan dengan studi yang dilakukan oleh Melani dan Wahidahwati (2017) serta Tjipto dan Juniarti (2016) yang menyatakan ukuran perusahaan (firm size) tidak berpengaruh terhadap nilai perusahaan.

Variabel kontrol leverage berpengaruh negatif signifikan terhadap nilai perusahaan. Berdasarkan uji statistik dapat dijelaskan bahwa secara parsial leverage berpengaruh negatif signifikan terhadap nilai perusahaan, hal ini dibuktikan dengan nilai standardized beta coefficients sebesar -0,192 dengan probabilitas signifikan sebesar 0,036 . Nilai signifikansi 0,036 lebih kecil dari 0,05. Berpengaruh negatif artinya leverage dengan nilai perusahaan memiliki arah yang berbeda dengan kata lain semakin tinggi rasio leverage yang dimiliki perusahaan perbankan maka nilai perusahaan menurun. Hal ini karena perusahaan dengan tingkat leverage yang tinggi termotivasi untuk melakukan manajemen laba agar terhindar dari pelanggaran perjanjian utang. Kontrak utang biasanya berisi tentang ketentuan bahwa perusahaan harus menjaga tingkat leverage tertentu dan ekuitas para pemegang saham (Sam'ani, 2008). 
Implikasinya ada kecenderungan manajemen melakukan manajemen laba pada laporan keuangan, yang akhirnya menurunkan kinerja perusahaan yang berdampak dapat menurunkan nilai perusahaan. Hasil penelitian ini sejalan dengan hasil penelitian yang dilakukan oleh Rahmadani dan Rahayu (2017) yang menyatakan adanya pengaruh leverage terhadap nilai perusahaan.

Hubungan antara variabel kontrol profitabilitas terhadap nilai perusahaan menunjukkan adanya pengaruh signifikan. Berdasarkan uji statistisk pada tabel 2 dapat dijelaskan bahwa secara parsial profitabilitas berpengaruh positif signifikan terhadap nilai perusahaan, hal ini dibuktikan dengan nilai standardized beta coefficients sebesar 0,378 dengan probabilitas signifikan sebesar 0,001. Nilai signifikansi 0,001 lebih kecil dari 0,05 dengan arah koefisien positif. Berpengaruh positif artinya semakin tinggi profitabilitas perusahaan maka semakin tinggi nilai perusahaan yang dimiliki. Profitabilitas yang tinggi menunjukkan prospek perusahaan yang bagus sehingga investor akan merespon positif dan nilai perusahaan akan meningkat. Peningkatan laba bersih perusahaan akan meningkatkan tingkat pengembalian investasi berupa pendapatan deviden bagi investor. Hasil penelitian ini sejalan dengan penelitian yang dilakukan oleh Ernawati dan Widyawati (2015) yang menyatakan bahwa profitabilitas berpengaruh terhadap nilai perusahaan.

Temuan penelitian ini menjelaskan bahwa pengungkapan CSR sebuah perusahaan belum tentu dapat meningkatkan nilai perusahaan karena investasi CSR dapat dipandang sebagai cash outflow bagi investor sehingga dapat berpotensi berdampak negatif bagi nilai perusahaan. Meskipun di sisi lain CSR juga merupakan investasi jangka panjang yang dapat menciptakan nilai bagi perusahaan. Hasil penilaian tata kelola perusahaan memberikan informasi sejauh mana manajemen bank sudah menerapkan prinsip corporate governance dalam mengelola perusahaan guna mencapai kepentingan stakeholder. Informasi hasil penilaian self assessment GCG yang baik memberikan sinyal positif adanya jaminan kinerja perusahaan yang lebih baik dalam mengoptimalkan laba perusahaan, berkurangnya kemungkinan pelanggaran atau kecurangan oleh pihak manajemen sehingga meningkatkan kepercayaan investor untuk berinvestasi pada perusahaan.

\section{Kesimpulan, Implikasi dan Keterbatasan}

Penelitan ini bertujuan untuk menguji pengaruh pengungkapan Corporate Social Responsibility (CSR) dan Good Corporate Governance (GCG) terhadap nilai perusahaan dengan firm size, leverage, dan profitabilitas sebagai variabel kontrol. Pengujian dilakukan pada 32 perusahaan perbankan yang terdaftar di Bursa Efek Indonesia (BEI) dengan periode pengamatan tiga tahun yaitu tahun 2015 sampai dengan tahun 2017. Hasil dari penelitian ini menunjukkan bahwa pengungkapan Corporate Social Responsibility (CSR) tidak berpengaruh signifikan terhadap nilai perusahaan, namun Good Corporate Governance (GCG) berpengaruh signifikan negatif terhadap nilai perusahaan. Ukuran perusahaan sebagai variabel kontrol tidak berpengaruh signifikan terhadap nilai perusahaan, namun demikian variabel kontrol leverage berpengaruh signifikan negatif terhadap nilai perusahaan dan profitabilitas berpengaruh signifikan positif terhadap nilai perusahaan. Temuan ini mengindikasikan bank dengan predikat GCG yang baik dan profitabilitas yang tinggi serta leverage yang semakin rendah akan mampu meningkatkan nilai perusahaan.

Implikasi penelitian ini dapat memberikan masukan bagi regulasi untuk lebih mendorong semua perusahaan yang terdaftar di BEI terutama perbankan untuk melakukan kegiatan CSR sebagai salah satu wujud kesadaran dan tanggung jawab sosial perusahaan terhadap masyarakat meskipun CSR diwajibkan oleh Undang-Undang 
nomor 40 tahun 2007 tersebut bagi perusahaan ekstraktif, namun juga dapat dilakukan oleh perusahaan fasilitatif seperti perbankan. Selain itu, badan regulator dapat meningkatkan kualitas standar Peraturan Otoritas Jasa Keuangan Nomor 55 Tahun 2016 Tentang Penerapan tata kelola bagi bank umum karena dalam rangka meningkatkan kinerja bank, melindungi kepentingan para pemangku kepentingan, dan meningkatkan kepatuhan terhadap peraturan perundang-undangan, diperlukan pelaksanaan tata kelola yang baik.

Hasil penelitian ini dapat dikembangkan pada penelitian-penelitian dengan topik yang relevan di masa yang akan datang, dengan mempertimbangkan beberapa keterbatasan dalam penelitian ini. Penelitian ini hanya menguji pada perusahaan perbankan yang terdaftar di Bursa Efek Indonesia dengan periode pengamatan selama tiga tahun yaitu tahun 2015-2017 sehingga memiliki rentang waktu observasi yang relatif pendek. Pada hasil uji koefisien determinasi $\left(\mathrm{R}^{2}\right)$ sebesar $18,7 \%$ memiliki tingkat prediksi model yang relatif lemah dalam menjelaskan variasi dari variabel penjelas nilai perusahaan. Dengan demikian penelitian mendatang dapat mengeksplorasi variabel lain yang dapat mempengaruhi nilai perusahaan, misalnya keputusan investasi, keputusan pendanaan, dan kebijakan deviden (Fenandar dan Raharja, 2012). Selain itu untuk mengukur Good Corporate Governance (GCG) tidak hanya dari hasil self assessment saja, karena bisa jadi dapat memberikan hasil yang subjektif sehingga penelitian mendatang dapat menggunakan pengukuran lainnya seperti indeks persepsi tata kelola (corporate governance perception index) maupun proksi GCG lainnya seperti jumlah dewan komisaris, jumlah direksi, komite audit dan sebagainya.

\section{Referensi}

Azheri, Busyra. 2012. Corporate Social Responsibility. Jakarta: PT Raja Grafindo Persada.

Buol Ronny adolof, 2014. "Dibawa lari, kemana sisa uang 4 miliar Milik BNI Manado". www.kompas.com. Di download tanggal 4 april 2018 jam 03:06 AM.

Debby, J.F. Mukhtaruddin, Emylia, Y. Dewa, S. Abukosim. 2014. Good Corporate Governance, Company's Characteristics and Firm Value: Empirical Study of Listed Banking on Indonesian Stock Exchange. GSTF Journal on Business Review, 3 (4), 81-87.

Ernawati, Dewi. Dini, Widyawati. 2015. Pengaruh Profitabilitas, Leverage Dan Ukuran Perusahaan Terhadap Nilai Perusahaan. Jurnal Ilmu \& Riset Akuntansi, 4 (4).

Fenandar Gany Ibrahim. Surya Raharja. 2012. Pengaruh Keputusan Investasi, Keputusan Pendanaan, Dan Kebijakan Dividen Terhadap Nilai Perusahaan, Diponegoro Journal of Accounting, 1 (2), 1-10.

Fiadicha, F. Rahmawati, Hanny.Y. 2016. Pengaruh Good Corporate Governance, Corporate Social Responsibility Dan Kinerja Keuangan Terhadap Nilai Perusahaan. Jurnal Akuntansi Manajerial, 1 (1), 22-45.

Fitri, Riana, A. Eliada, Herwiyanti. 2013. Pengaruh Corporate Social Responsibility Dan Good Corporate Governance Terhadap Nilai Perusahaan. Universitas Jenderal Soedirman.

Ghozali, Imam. 2005. Aplikasi Analisis Multivaret dengan Program SPSS. Semarang: Badan Penerbit Universitas Diponegoro.

Hamdani. 2016. Good Corporate Governance Tinjauan Etika Dalam Praktik Bisnis. Mitra Wacana Media: Jakarta.

Horne, James, C.V. John, M. Wachowiz, Jr. 2012. Prinsip-Prinsip Manajemen Keuangan. Jakarta: Salemba Empat. 
Jensen, M.C. W.H. Meckling. 1976. Theory of The Firm: Managerial Behavior, Agency Cost and Ownership Structure. Journal of Financial Economics, 3 (4), 305-360.

Kebon, Sang, M, A, M. I, Ketut, S. 2017. Pengaruh Good Corporate Governance Dan Investment Opportunity Set Pada Nilai Perusahaan Di Bursa Efek Indonesia. EJurnal Akuntansi Universitas Udayana, 20 (2), 1534-1563.

Kusumaningtyas, Titah, K. Andayani. 2015. Pengaruh Good Corporate Governance Terhadap Nilai Perusahaan Yang Terdaftar Pada Indeks Sri-Kehati. Jurnal Ilmu \& Riset Akuntansi, 4 (7).

Lisyanti, S.E. Catur, Fatchu, U. 2017. Pengaruh Kinerja Keuangan, Corporate Social Responsibility Dan Good Corporate Governance Terhadap Nilai Perusahaan Perbankan Yang Terdaftar Di Bursa Efek Indonesia Tahun 2013-2015. Universitas Riau Kepulauan.

Mardikanto, Totok, 2014. Tanggung jawab Sosial Korporasi. Bandung: Alfabeta.

Martono, Nanang. 2016. Metode Penelitian Kuantitatif: Analisis Isi dan Analisis Data Sekunder. Jakarta: PT Raja Grafindo Persada.

Melani, Silistia dan Wahidahwati. 2017. Pengaruh GCG dan CSR terhadap Nilai Perusahaan dengan Profitabilitas sebagai variabel moderating. Sekolah Tinggi Ilmu Ekonomi Indonesia (STIESIA) Surabaya

Nurcholis, Septian, 2013 Pengaruh Corporate Sosial Responsibility Disclosure Terhadap Nilai Perusahaan Perbankan.Skripsi. Universitas Pendidikan Indonesia.

Peraturan Otoritas Jasa Keuangan Nomor 55 /POJK.03/2016 Tentang Penerapan Tata Kelola Bagi Bank Umum.

Prasetyorini, Bhekti, Fitri. 2013. Pengaruh Ukuran Perusahaan, Leverage, Price Earning Ratio Dan Profitabilitas Terhadap Nilai Perusahaan. Jurnal Imu Manajemen, 1 (1), 183-196

Pujana, Gede, A, W. 2016. Pengaruh Good corporate governance dan corporate social responsibility terhadap nilai perusahaan dengan profitabilitas sebagai variabel mediasi (studi empiris pada perusahaan perbankan yang terdaftar di Bursa Efek Indonesia Tahun 2012-2014). Tesis. Universitas Arilangga Surabaya.

Rahmawati, Amalia, D. Topowijono. Sri S. 2015. Pengaruh Ukuran Perusahaan, Profitabilitas, Struktur Modal, Dan Keputusan Investasi Terhadap Nilai Perusahaan (Studi Pada Perusahaan Sektor Properti, Real Estate, Dan Building Construction Yang Terdaftar Di Bursa Efek Indonesia (BEI) Periode 20102013). Jurnal Administrasi Bisnis, 23 (2), 1-7.

Retno, R, D. Denies, Priantinah. 2012. Pengaruh Good Corporate Governance Dan Pengungkapan Corporate Social Responsibility Terhadap Nilai Perusahaan (Studi Empiris Pada Perusahaan Yang Terdaftar Di Bursa Efek Indonesia Periode 2007-2010). Jurnal Nominal, 1 (1), 84-103.

Sam'ani. 2008. Pengaruh Good Corporate Governance Dan Leverage Terhadap Kinerja Keuangan Pada Perbankan Yang Terdaftar Di Bursa Efek Indonesia (Bei) Tahun 2004 - 2007. Tesis. Universitas Diponegoro Semarang.

Sari, Roosiana, A, I. Maswar, Patuh, P. 2016. Pengaruh Leverage, Profitabilitas, Size, Dan Growth Opportunity Terhadap Nilai Perusahaan. Jurnal Ilmu dan Riset Manajemen, 5 (10), 5-7.

Stacia, Evelyn. Juniarti. 2015. Pengaruh Pengungkapan Corporate Social Responsibility Terhadap Nilai Perusahaan Di Sektor Pertambangan. Business Accounting Review,3 (2), 81-90.

Suchman, Mark, C. 1995. Managing Legitimacy: Strategic and Institusional Approaches. Academy of Management Review, 20 (3), 571-610. 
Sugiyono. 2012. Metode Penelitian Kuantitatif, Kualitatif, dan R\&D. Bandung: Alfabeta.

2017. Statistika Untuk Penelitian. Bandung: Alfabeta.

Surat Edaran Otoritas Jasa Keuangan Nomor 13 /SE.OJK.03/2017 Tentang Penerapan Tata Kelola Bagi Bank Umum.

Tjandra Aditia. 2018. "Kasus pembobolan bank, gaya hidup jadi faktor pendorong". https://kriminologi.id. Di download tanggal 4 april 2018 jam 02:30 AM.

Tjipto, Elsa, P. Juniarti. 2017. Pengaruh Corporate Social Responsibility Terhadap Nilai Perusahaan Pada Sektor Property and Real Estate. Business Accounting Review, 4 (1), 24-36.

Www.idx.co.id (Diakses 8 April 2018

(www.globalreporting.org)

Ycharts. 2018. Bank Mandiri (Persero) price to book value". https://ycharts.com. Di download tanggal 16 Maret 2018 jam 10:15 AM. 